\title{
Researching The Practice of Inclusive Education in Indonesian Pesantrens (Islamic Boarding Schools)
}

\author{
Mardiyanti \\ Paediatric Department, School of Nursing \\ Faculty of Medicine and Health Science \\ Syarif Hidayatullah State Islamic University \\ Jakarta Indonesia
}

\author{
Rasid \\ Islamic Science, Ma'had Ali of UIN Dormitory \\ Syarif Hidayatullah State Islamic University \\ Jakarta Indonesia
}

\begin{abstract}
Negative image has been posed around Indonesian pesantrens as it close to terrorism and radicalization. In fact, Pesantren has a very limited supports from the government but keep educating people, including people with disabilities, as part of their worship to God. This article investigates practices of pesantrens in providing access to Indonesian with disabilities. The article also explores religious values and ethics that promote inclusive education within pesantrens. This paper demonstrates that some elements of inclusive education have been implemented in Indonesian pesantrens. The pesantrens welcomed students with disabilities although with very less supports in term of facilities. Besides, many parents believed that pesantrens are the best place to develop well manner beside good knowledge and morality of their children, including children with disabilities. I start the paper with a discussion of the conceptual framework of Islamic education and pesantrens. I then discuss the research setting of two pesantrens and the methodology followed by the findings and a discussion to describe social interaction within Indonesian context.
\end{abstract}

Keyword: Pesantren, Disability, Inclusive education, Indonesia

\section{INTRODUCTION}

It is estimated that around $15 \%$ of world population has a disability, and $80 \%$ of the population were living in developing countries [1]. Indonesia as one of developing countries and one largest Muslim country around the world has around 1.5 million $(2 \%)$ of children with disabilities [2]. However, parents of these children tend to keep the children at home rather than sending them to school [2]. In fact, the regulation of inclusive education has been enacted almost a decade ago to maintain equal rights of education for People with Disabilities (PWDs). Pesantrens on the other hand, has a long history as one of educational institution which has been viewed by parents as a good place to develop well manner beside good knowledge and morality of their young children. However, little information has been known whether pesantrens practising inclusive education as they are one of Indonesian traditional Islamic educational institution who are independent.

\section{CONCEPTUAL FRAMEWORK}

Conceptual framework has been developed to broaden our knowledge of what theory related to the research problems as well as practice around the world. Conceptual framework in this study includes concept of education in Islam, pesantrens and inclusive education in Indonesian context.

\section{A. Concept of education in Islam}

The concept of education in Islam differs with liberal. While in Islam, all knowledge has religious significance and thus religion become the centre of all educational activities. Moreover, knowledge and education are embedded in religion (Qur'an and Syari'a) thus cannot be secularized as in most liberal view $[3,4]$. Therefore any pursuit of knowledge is regarded as a form of worship in Islam as long as it is undertaken within the boundaries of Qur'an and Syari' $a$ (Quran 58:11 and 39:9).

The aim of education in Islam is 'to produce good Muslims with an understanding of Islamic rules of behaviour and a strong knowledge of and commitment to the faith' [4]. Furthermore, "Ref [4]" explains that education has three different meanings adapted from Arabic language as follows; Tarbiya or individual development; Ta'dib or social and moral development, and Ta'lim or acquisition of knowledge. Meanwhile "Ref [5]" added moral values that become the fundamental of education include the unity of God (Tawhid), humanity, egalitarian and on top of them is a blessing for everyone (rahmatan lil alamin).

Unity of God requests the believers to believe that the God is one and always monitor their life [5]. All human has been ordered to do what is halal (permitted) and to leave what is haram (forbidden) as it explained in the Syari'a. Humanity refers to equal rights and equal responsible, means that every 
human being has equal rights in education and equal responsible to transfer their knowledge to others, and helping other in search of their knowledge [4]. The God says that "O Mankind! We created you from a male and female and from different nations and tribes in order to make you know each other, verily the noblest among you in the sight of Allah is the most pious among you" (Quran 49:13). In addition, one hadith of Bukhari collections mention that "seeking for knowledge is obligatory for every Muslim man and woman" [4]. Thus in muslims view studying and teaching can be a bridge to be a pious muslim. Meanwhile, egalitarian $(a l A d l)$ refers to life balance; means that every aspect in education is relate each other in order to prevent justice for every human being [5]. If the principle of tawhid (unity of God), humanity and egalitarian have been developed, there will be a blessing for everyone either in the world or in the life after, as saying in Quran 21:107.

Furthermore, according to "Ref [4]" there are two concepts of knowledge in Quran. Firstly, knowledge can be revealed or transmitted science (naqliyya) e.g. theology and jurisprudence; secondly, knowledge can be humanly constructed (aqliyya) which means that knowledge must be approached reverently and in humility, there cannot be any 'true' knowledge that is in conflict with religion and divine revelation, but may only ignorance. The implication of these sayings reminds the believers that the first request from Allah to all mankind is to study and learn; indicating how important studying and learning in Islamic educational philosophy.

\section{B. Pesantren}

Pesantren is a religious, traditional boarding schools, aim to understand and practice the teachings of Islam (tafaqquh fi al-din) by emphasizing the importance of Islamic morality as a guidance of daily life, entirely under the sovereignty of the leadership of one or several Kyai with charismatic and independent in all respects [6,7]. According to Ministry of Religion Affairs (MoRA), the number of pesantrens has increased significantly from 4,196 pesantren in 1997 to 27,230 pesantrens in 2012 [8]. Ideally, pesantrens are open for anyone who willing to study Islam or developing well manner and spiritual of their children, disregards of the disability of someone has. However, due to modernization and increasing demand of developing life skills of pupils, since 1990s pesantren has developed into pesantren Salafiyah (traditionalist) and pesantren Khalaf (modern) with the last type is adopting national curriculum alongside with religious instructions $[9,10]$. The traditionalist focuses on religious teaching and character development in order to produce Islamic leader or Ulama. The religious teaching includes; Tawhid, tafsir, 'ulum al-Quran, hadith, fiqh, ushu al fiqh, qawaid al-fiqh, tarikh, tasawuf, akhlaq,faraidl and Arabic language [7].

Pesantren is also known as an Islamic boarding school in which students live and study together with the Islamic scholar or Kyai and use segregation system between male and female students [7]. Religious teaching is based on the study of Kitab Kuning or yellow book (printed in the yellow paper) formed by prominent Muslim scholars in the Middle east from the tenth to the fifteenth century [7]. The goal of pesantrens is to maintain the classical Islamic tradition of education into daily routines. Daily routine of the students in pesantrens where this research undertaken as explain in table 1:

TABLE 1.

SCHEDULE AT PESANTRENS

\begin{tabular}{|c|l|}
\hline Time & \multicolumn{1}{|c|}{ Activities } \\
\hline 03.30 AM & wake up, prepare for praying tahajud \\
\hline 03.30 AM & salat tahajud \\
\hline 04.00 AM & Istigosah or intelligence therapy \\
\hline 04.15 AM & Shubuh praying \\
\hline 05.00 AM & $\begin{array}{l}\text { Language skills (Arabic/English) Monday to } \\
\text { Thursday Study of Yellow Book (Friday to } \\
\text { Saturday), and exercise on Sunday }\end{array}$ \\
\hline 06.00 AM & Breakfast \\
\hline 07.00 AM & Pray Dhuha \\
\hline $07.30-12.30$ & Formal school (Government curriculum) \\
\hline $12.30-13.00$ & Pray Dhuhur \\
\hline 13.00-15.30 & Lunch, rest \\
\hline 15.30-16.00 & Pray Ashar \\
\hline $16.00-17.30$ & Islamic teaching from yellow book, Qur'an \\
\hline $17.30-18.00$ & istigosah (mysticism or sufism) \\
\hline $18.00-18.30$ & Pray Magrib \\
\hline $18.30-19.00$ & Qur'an study \\
\hline $19.00-20.00$ & Dinner, rest \\
\hline 20.00-20.30 & Pray Isya \\
\hline $20.30-22.00$ & Study formal subjects, or kitab or practice preacher \\
\hline $22.00-03.30$ & night sleep \\
\hline
\end{tabular}

"Reference [9] and [10]" described that there are 5 forms of pedagogy in pesantren includes: memorizing, wetonan or bandongan, sorogan, muzhakaroh and majlis ta'lim. Memorizing is the main form of individual learning that requires students to memorize the Kitab or classical text which is in Arabic language has been explained by the Kyai. Wetonan characterized by the Kyai initiative in deciding the topic, place and time of study. During study, the Kyai read the Kitab in front of all pesantren students in Arabic, and then read the translation inIndonesian language. Sorogan involves the individual study and then read in front of the class of what the individual has studied to be 
corrected by the Kyai. Muzhakaroh is a study group that students are required to present in front of others. Majelis Ta'lim involves all element of society around the pesantren to come and study general topic of Islam in a regular period.

\section{Inclusive education}

Inclusion refer to "a sense of belonging, feeling respected, valued for what you are; feeling a level of supportive energy and commitment from others, so that you can do your best work" [11]. Three principles of inclusive education include: enable full capability, parity of participation and make disability ordinary [12]. These three principles aim to enable PWDs to reach their full capability and participate on par with their non-disabled counterparts.

Within Indonesia, education is provided and regulated either under Ministry of Education (for secular, non-religious schools) or MoRA for religion schools [7]. This dual system occurs because of Muslim leaders and educators believed that MoRA was the only government institution with the expertise necessary for evaluating the competency of the Islamic schools apart from preventing secularism [7,9]. By the release of three minister joint decree in 1975, a universal curriculum for Islamic schools has been standardized and then accepted in most Islamic schools and some pesantrens who seek formal recognition. The joint decree plays important role in accommodating the demands of Muslim leaders who want to maintain the faith, and Muslim parents who seek schools that teach necessary skills and knowledge to fit with modern job market while maintaining religious practices $[7,9]$.

However, in regard of inclusive education, MORA does not have institutional policy compare to Ministry of Education [13]. Because of this, religion schools may not accept student with disability which contrary to the government commitment in the UN Convention on Rights of People with Disabilities (UNCRPD). Ministry of Education on the other hand, regulates education for PWDs under the Law No 20/2003 on Indonesia national education system [13]. The regulation stipulates special education for anyone with physical impairment, emotional, mental, intellectual, and social disabilities. However special education creates segregation and marginalisation which preventing disabled children with their natural learning environment.

Furthermore, Indonesia enacted law number $70 / 2009$ to support inclusive education. Specific under Article number 3 of the Law stipulates that students who have physical, emotional, mental, and social or has intelligence and / or special talents are eligible for inclusive education based on their specific needs and abilities. Moreover, Article number 4 of the Law mention that municipality or state are required to choose minimum 1 public school to organized inclusive education in their local areas. The local government guarantee the provision of inclusive education in local areas as well as provided supports and additional needs that may require by the disabled students (article number 6 of the Law 70/2009).

\section{METHODOLOGY}

This research presents a multiple case studies which explore the perspective of Kyai (pesantren leader), teachers, parents and non-disabled students in their interactions with disabled peers in the two pesantrens. The questions posed in this interviewbased project were about how pesantren have worked to promote accessible and inclusive education for Indonesian Muslims as well as Islamic values within these practice. In-depth interview and Focus Group Discussion (FGD) have been used to collect data. Themes revealed from the interviews of one Kyai (Riyadul Jannah); several interviews from Lurah putera and puteri (male and female Pesantren manager) and Director of Madrasah of both pesantrens, few interview and two FGDs with teachers, few interview and three FGDs with non disabled students, several interviews with disabled students, and two interviews of parents of disabled students from both pesantrens have been made including sitting in the class where disabled students around. Note that the Kyai of Assadiqiyah were having a chronic disease and hospitalized during data collection. The son of the Kyai as the temporary leader in the pesantren was difficult to reach. Data collection held from August to December 2016.

\section{RESEARCH SETTING}

The research was conducted in two pesantrens named Assidiqiyah (located in Indonesian capital city) and Riyadul jannah (located in rural west Java). Assidiqiyah was established in 1985 located in Kedoya west Jakarta, with the founder DR.KH. Noer Muhammad Iskandar, SQ. The pesantren areas are about 2000 metre square consist of one-large ground for outdoor activities such as soccer which surround by four main building with four floors and one of the building has a large mosque at the first floor, two main-dormitory buildings for female and male, one large house of the kyai, some medium-houses for teachers and a relatively small parking areas made the location seems crowded and less structured. In term of teaching, there are 4 departments include madrasah Tsanawiyah Islam Manba'ul Ulum (Junior High School), Madrasah Aliyah Manba'ul Ulum (Senior High school), Ma'had Aitam Saa'idusshiddiqiyah (Tahfidzul Quran), and Ma'had Aly Saa'idusshiddiqiyah (Bachelor degree of Islamic studies). Another pesantren named Riyadul Jannah consist of Junior and Senior high school only. This pesantren is larger than 
Assidiqiyah, less crowded with larger ground for outdoor activities and surrounds with many planted trees creates a better green environment besides many old two-floor buildings inside with stairs made it less accessible for people with wheelchair. Moreover, both pesantrens offer cheap institution's fee (around 600-900 thousand rupiah per month) including three times meals and a laundry services, similar to most pesantrens that offering cheap educational services provided for low to middle economic-class [18]. Similarly, both pesantrens impose life separation between male and female students, strict rules (no cellphone, TV, or other electronic devices), demanding schedules (from 3 AM to 10 PM) and adopt the Ministry of religion's curriculum for Madrasah schooling system, which known as modern pesantren. The significant different of both pesantrens is that the quality of the teachers. Some of Riyadul Jannah teachers are alumni of the pesantren with a Senior High School background. Some of these teachers are responsible for teaching islamic studies, Math and language. Meanwhile, Assidiqiyah teachers are mostly graduated from Bachelor degree. Assidiqiyah differentiate between alumni and teachers. Alumni are responsible as a "wali asuh" which means their job is monitoring the students' behaviour and discipline only, they cannot teach formal subjects in front of the class. Assidiqiyah has been well-known for its reputation internationally; therefore some international students (Thailand) have been studying in the pesantren.

\section{FINDINGS}

\section{A. Disability in the eyes of Kyai, teachers and students}

In the eyes of Kyai and teachers, disability is not a punishment of being bad Muslim parents but as a challenge to the person themselves, their parents and society to increase their pious in order to get rewards in the world and in the life after.

"innal hayata wal mauta liyabluwakum ayyukum ahsanu 'amala”. Life and death are things that make your faith develop. So when you were given a disabled child, which Allah mandate you to look after, then accept with pride, not as a punishment, as you has been chosen. (Kyai of Riyadul Jannah $(\mathrm{RJ})$ )

The Kyai of pesantren Riyadul Jannah highlight that disabled children is a mandate for every parent, and not as a punishment.

"kulu mauludin yuradural fitrah" "all children come with their nature... $i$ believe that the disabled children brought their own nature that we need to enable to make them success. (SMP Headmaster of $R J)$
The headmaster of Pesantren Riyadul Jannah believed that disabled children bring their own nature that make them difference with other normal peers. Therefore enabling the child based on their own nature would make them success in their life.

"In Islamic view, for those who has a disability or special needs, there still a space, to double their rewards. Why? Because of the limitation, they have already the rewards, but when they have willingness to study, these means double-double rewards... (Ma'had Aytam Headmaster of Pesantren Assidiqiyah)

The Headmaster of Ma'had Aytam (school of orphan children) in Pesantren Assidiqiyah added that those who have disability and they still have motivation to study, are granted double rewards from the God.

"There are two types of disability, first is physical and second is mental disability. They have equal rights and responsible in performing ibadah, depend on their intellectuality, if they can differentiate between good deed and bad deed, become mature. but as Allah says: "laa yukalifullohu nafsan illa wus'ahaa", a man is not burdened with task except according to his ability". (Assidiqiyah male community Leader)

The male community leader (the Kyai first man) of Assidiqiyah pesantren explained the two type of disability: physical and mental. Both types have equal rights and responsibility in performing religious instructions as other non disabled people, including the same responsibility in performing ibadah (the divine Law) as long as the disabled people can differentiate between the good thing and the bad things; if he or she can do it, this means the child has mature. Importantly, even the disabled child has mature but face difficulties in performing ibadah, then he/she may be granted rukhshah (remission) because of his disability.

This means greater reward for us if we handle the special needs because it takes patience that is different from the others ... attawabu ala qadimi shokhokh "the amount of the reward depends on the severity of the constraints we are in" the more the obstacle then the greater the reward. That is source of rewards... (Headmaster of RJ)

Most participants believed that teaching children with disability will bring abundant rewards because of their belief to the value of patience and obedience as a good Muslim .

In addition, one of alumni who has visual impairment explain that when he want to register to 
one of pesantren, the Kyai accepted him because of fear on making sin if he rejected a blind people in search of knowledge, as saying in Qur'an Surah Abasa 80:1-12; the Prophet frowned and turned away from a blind man when talking to other man who was a leader and ignored the blind man. As a result Allah reminds Him not to behave like that.

"I was grateful that the Kyai accept me to study in pesantren based on Quran Abasa, he said that he afraid of making sin, you know..."

The non disabled students have positive views about disabled students and they believed that every human being is equal except their fear of God.

"In our class we have a friend with visual impairment, cataract..but ya we merged, because we all aqual, no different, the only difference in the eye of God is certainty" (Student without disability in grade 8 Assidiqiyah)

To conclude, Kyai, teachers and students have positive values about disability. These values include equality, humanity, piousness and self restraint of becoming a good Muslim.

\section{B. Acceptance as a moral obligation}

The Kyai and teachers were having positive values toward people with disabilities. These include accepting anyone with disability who willing to study in the pesantrens.

"Pesantren never reject anyone who willing to study...we welcome... as long as they have motivation to study..." (Male community leader, assidiqiyah and Kyai RJ)

Kyai and teachers believe that everyone has a moral obligation to equal access for all students. However one of the female community leaders felt incapable thus she preferred the disabled children to be educated in special schools.

I think they need special schools, because our limitation, they need extra caring...except they have high motivation...but personally $i$ can't.. (Grins) even managing normal students would take energy... (Female community leaders of Assidiqiyah)

However, most participants explained that they accepting the child, even there was an entry test and the students were being test based on academic performance and ability of reading Qur'an. The participants explained that the decision of accepting disabled children is the priviledge of the Kyai.

"No...we don't have the policy or regulation, depend on the Kyai..." (Male Community Leader, Asisiqiyah)
Although pesantrens accept students with disability, the Kyai and teachers considered with limited facilities such as inaccessible buildings and skills of the teachers.

"Pesantren should provide access to PWDs to study, the building should be accessible and good structure, however, we lack of support from the government compare to public schools...therefore $i$ myself suggest parents to put children with disability in inclusive educational institutions where competent teachers are there" (Female community leader pesantren $R J$ ).

Therefore, before student's acceptance, the Kyai and teachers explain their limitation to parents including asking for additional fees possibility. The Kyai explained that extra teachers and materials are required to support the learning goals, but it depends on the parents' ability. Based on observation, there were also two students with intellectual disability whom parents could not provide additional fees but still accepted in the pesantren.

In addition, although there is no guideline or policies on inclusive education, the teachers explained that they accept students with disabilities based on revealed knowledge; the hadith (Prophet Sayings). One of the Hadith as stated by the teacher was Tholabul ilmi faridhotun ala kulli Muslimin (Hadith Ibnu Majah number 224) meaning that studying is an obligation for each individual including People with Disabilities, therefore when someone is looking for a school, the pesantren accepted and supported the students as part of helping someone to do their obligation, they believed that every human are equal disregard of their disability.

\section{Integrated rather than inclusive method}

Because of no policy and regulation of inclusive education, the practice of inclusive education was limited. Although pesantrens accepted students with disabilities, the students need to adjust with the situation by themselves.

" $i$ think it's integrated method, not inclusive. Because $i$ have to adapt with the environment by myself" (Alumni).

The headmaster of SMP Pesantren Assidiqiyah explained type of support that he provided to disabled students.

"Previously we had blind student, we provided room for him close to the mosque, so easier for him to pray, we also read him questions during exam, but he then quit from the school, don't know why but $i$ think because he can't adapt with" (Headmaster of SMP Assidiqiyah). 
The pesantrens had no special curriculum for disabled students; there was only curriculum for non disabled students. However, extra teacher and additional time were given in order to support the child with disability as well as lowering task if the child cannot achieve the learning objectives.

"We modified the exam, for example if the child (with intellectual disability) prefer to memorizing Qur'an then we give score based on it, rather than scoring on other topic that he cannot mastering" (headmaster of Ma'had Aytam Assisidiqiyah).

In the view of some teachers and headmasters, academic performance should not be the only form of intelligence, but should rely on other form such as attitudes and moral behaviour.

"During his stay, as long as he still joins the congregation, reading Quran, although his academic performance can never be the same with others, we consider that he can enter next level..."

\section{DISCUSSION}

The philosophy of inclusive education has similar point in Islamic teaching. Islam teaches inclusion in all aspect of life; as mention in Quran 21:107, and Islam opposes any form of exclusion of certain group of people because of their physical appearance, ability and disability [16]. Based on the findings above, pesantrens accept students with disabilities, but without fully supported with regulation and documentation. As a result, parents may not know that pesantrens accept children with disabilities. The candidates of the students need to find by themselves about the possibility of studying in the pesantrens. Moreover, the students with disability need to adapt with the situations as there limited building access, limited assistive devices, limited curriculum and none special teachers available. However, the two pesantrens in this study applied Islamic values based on Qur'an and Hadith to help disabled students in search of knowledge in the pesantrens life.

\section{REFERENCE}

[1] World Health Organization. [Online]. Available: www.who.int/disabilities/world_report/2011/en/

[2] International Labour Organization. [Online]. Available: www.ilo.org/wcmsp5/groups/public/@asia/Arobangkok/@ilo-

jakarta/documents/publication/wcms 165280.pdf

[3] O.H. Kasule, "Incorporating moral values and maqasid al-shari'ah into medical and health sciences," presented at the $2^{\text {nd }}$ world congress on integration and islamicisation focus on medical and health sciences, Kuantan, MAS, October 21-23, 2016.
[4] J.M. Halstead, "Islamic values: a distinctive framework for moral education," Journal of Moral Education, vol.36, no.3, pp. 283-296, 2007.

[5] A. Nata, Filsafat pendidikan Islam. Yogyakarta, DIY: Ar-Ruzz Media, 2011.

[6] S.H. Hamzah, "Perkembangan pesantren di Indonesia era orde lama, orde baru," Syamil, vol.2, no.1, pp.1-14, 2014.

[7] A. Subhan, Lembaga pendidikan Islam Indonesia abad ke-20: pergumulan antara modernisasi dan identitas. Jakarta, JKT: UIN Jakarta Press, 2010

[8] Indonesia Ministry of Religion Affairs. [Online]. Available: www.ditpdpontren.kemenag.go.id

[9] M. Zuhdi, "Modernization of Indonesian islamic schools' curricula, 1945-2003," International Journal of Inclusive Education, vol.10, no.4-5, pp. 415-427.

[10] R.A. Lukens-Bull, "Two sides of the same coin: modernity and tradition in Islamic education in Indonesia," Antropology \& Education Quarterly, vo.32, no.3, pp. 350-372.

[11] A. Azra, "Indonesian Islam; diversity and disability inclusion," presented at the Conf. Of Diversity and Disability Inclusion in Muslim Societies: Experiences from Asia, Jakarta, INA, November, 21-22, 2017.

[12] K. Soldatic, "Inclusive education; creating life pathways for people with disability," presented at the Conf. Of Diversity and Disability Inclusion in Muslim Societies: Experiences from Asia, Jakarta, INA, November, 21-22, 2017.

[13] Global disability watch. [Online]. Available: http://globaldisability.org/2016/09/06/disabilityinclusive-education-indonesian-islamic-educationinstitutions 